ORIGINAL RESEARCH PAPER

\title{
NUTRITIONAL QUALITY AND STARCH DIGESTIBILITY OF BREADFRUIT-BAMBARA GROUNDNUT COMPOSITE FLOURS FOR FOOD FORMULATIONS
}

\author{
STEPHEN OLANREWAJU ARINOLA ${ }^{1 *}$, OLUFUNKE OLUSEYI EZEKIEL ${ }^{2}$, EUNICE \\ MORIYIKE OGUNBUSOLA ${ }^{3}$ \\ ${ }^{1}$ Department of Food Technology, Federal Polytechnic Ado-Ekiti, Ekiti State, Nigeria \\ ${ }^{2}$ Department of Food Technology, University of Ibadan, Oyo State, Nigeria \\ ${ }^{3}$ Department of Food Science and Technology, Federal University Oye Ekiti, Ekiti State, Nigeria \\ *corresponding author: lanrearinola2@gmail.com
}

Received on 6 September 2021

Revised on 2 December 2021

\begin{abstract}
The focus of this study was to produce composite flour with nutritional and functional potentials from underutilized and inexpensive crops, which can be used in food formulations as a substitute to composite flours from commonly used and expensive crops. The proximate, mineral, and amino acid compositions, resistant starch content and in vitro starch digestibility of breadfruit-bambara groundnut (100:0, 90:10, 80:20, 70:30, and 60:40 respectively) composite flours were investigated using standard methods. Data generated were subjected to statistical analysis. Inclusion of bambara groundnut in the composite flours significantly $(\mathrm{p} \leq 0.05)$ increased protein $(5.06-16.96 \%)$, ash $(1.54-2.71 \%)$, fat $(1.06-1.96 \%)$, potassium (727.82-797.73 $\mathrm{mg} / 100 \mathrm{~g}$ ), phosphorus (143.36-177.32 $\mathrm{mg} / 100 \mathrm{~g}$ ), magnesium $(92.71-117.05 \mathrm{mg} / 100 \mathrm{~g}$ ) and resistant starch (11.45-21.98\%) contents, while it significantly $(\mathrm{p} \leq 0.05)$ reduced fibre (4.65-5.39\%), carbohydrate (65.33$79.69 \%$ ), sodium (48. 64-71.25 mg/100g), and calcium (57.65-64.50 mg/100g) contents, as well as in vitro starch digestibility (40.41-58.75\%). All the essential amino acids were present; they constituted $34.69-37.94 \%$ of the total amino acid. The predicted protein efficiency ratio ranged from 2.14 to 2.82 . This study suggests that breadfruit-bambara groundnut composite flours may find usefulness in different food formulations and may exhibit lower postprandial hyperglycemia which is important for obese and diabetic patients.
\end{abstract}

Keywords: breadfruit, bambara groundnut, amino acid composition, resistant starch; physiological effects

https://doi.org/10.35219/foodtechnology.2021.2.09 


\section{Introduction}

Composite flours are a mixture of flours from roots/tubers rich in starch (e.g. cassava, yam, sweet potato) and/or legumes rich in protein (e.g. soybean, peanut) and/or cereals (e.g. maize, rice, millet) and/or flours from other sources (with appropriate nutritional and functional properties) with or without wheat flour (Noorfarahzihah et al., 2014). The concept of composite flour in food science and technology has been an innovative measure to reduce dependence on some commonly used crops that are known to be expensive and/or have certain health implications and to ensure maximum utilization of indigenous crops, especially those that are underutilized. It appears that the concept started with the idea of finding a suitable substitute for wheat flour in the production of bakery products. However, the application of composite flour has transcended the scope of bakery products to other products such as weaning food, pasta, dumpling dough, food analogue, etc. The advantages of composite flour include the promotion of high yielding native species, a better supply of protein for human nutrition, and better overall uses of agriculture production (Bugusu et al., 2001). These advantages are critical to ensuring food security before, during, and after the COVID-19 pandemic. Currently, the COVID-19 pandemic is negatively affecting the economy of most nations of the world with its attendant effects on food availability, food affordability, and food safety. One of the challenges in food science and technology is to develop a new product that, apart from its nutritional values, also has health benefits (Raihan and Saini, 2017). These challenges have broadened the scope of composite flour technology to include consideration of food crops that have useful health properties and can contribute to the prevention and management of some diseases in the body. Additionally, consumers are increasingly interested in foods that have health benefits. In respect to this, one of the health promoting factors in food is resistant starch. Resistant starch plays useful physiological roles in the body just like dietary fibre; it has been reported to have beneficial effects on insulin sensitivity and fatty acid metabolism in both healthy individuals and those with metabolic syndrome (Bodinham et al., 2014)

Breadfruit flour is produced from breadfruit. Breadfruit, which is grown in most southwestern parts of Nigeria, is relatively underutilized and cheap when compared with most food crops. The processing of the fruit into flour is a major means of reducing post-harvest wastage of the fruit. The nutritional and functional properties of breadfruit flour compare well with similar properties of flours from other food crops. The proximate composition of breadfruit flour is similar to that of wheat flour except that the protein content of wheat flour is twice that of breadfruit flour. Also, breadfruit flour has higher ash and fiber contents than wheat flour (Jones et. al., 2011). The flour has high water absorption and swelling capacity which make it fit for application in food production. Bambara groundnut is a dicotyledonous crop indigenous to Africa and grown across the continent primarily for its edible seed. It is rich in nutrients and some phytochemicals, the crop has $20.60 \%$ protein, $6.60 \%$ fat, $6.34 \%$ fibre, $3.24 \%$ ash, and $56.51 \%$ carbohydrate (Mazahib et al., 2013). Bambara groundnut is a leguminous underutilized crop and this is due to its hard- 
to-cook nature and limited information on its potential food uses (Oyeyinka, 2017). More research attention should therefore be given to the processing and utilization of this leguminous crop in food application in order to promote the crop and explore its nutritional and phytochemical properties. The objective of this study was to evaluate the nutritional composition, resistant starch content, and in vitro starch digestibility of breadfruit-bambara groundnut composite flours. This is expected to provide baseline information necessary for the application of composite flour in food formulations.

\section{Materials and Methods}

\section{Production of breadfruit flour}

Breadfruit flour was produced from freshly harvested matured unripe breadfruits; the breadfruits were washed, peeled, cored, and diced into pieces. Breadfruit pieces were dried in a hot air oven at $70^{\circ} \mathrm{C}$ for 10 hours. The dried breadfruit pieces were milled into flour using a hammer mill, sieved $(500 \mu \mathrm{m})$, and packaged in a high density polyethylene bag.

\section{Production of bambara groundnut flour}

Bambara groundnut flour was produced by soaking cleaned seed in water $(1: 4 \mathrm{w} / \mathrm{v})$ for 2 hours, the seeds were drained out of the water, parboiled $\left(100^{\circ} \mathrm{C}\right)$ for 15 minutes, and dehulled manually. Dehulled seeds were dried at $60^{\circ} \mathrm{C}$ for 24 hours in a hot air oven, milled into flour using a hammer mill, sieved $(500 \mu \mathrm{m})$, and packaged in a high density polyethylene bag.

\section{Formulation of breadfruit-bambara groundnut composite flours}

Five different composite flours were produced by mixing breadfruit flour with bambara groundnut flour in the following proportion 100:0; 90:10; 80:20; 70:30, and 60:40 respectively. Each sample was thoroughly mixed using an electric homogenizer; the composite flours were packaged in polyethylene bags and stored at ambient temperature.

\section{Determination of proximate composition and energy value}

The methods used for the determination of protein, fat, ash, fibre, and moisture content of the composite flours are AOAC (2005) Official Methods 2001.11(protein: Kjeldahl Method), 963.15 (fat: Soxhlet Extraction Method), 923.03 (ash) and 978.10 (fibre) and 925.10 (moisture); carbohydrate was obtained by difference. Energy content $(\mathrm{kcal} / 100 \mathrm{~g}$ ) was estimated using the Atwater factor.

\section{Determination of mineral composition}

Kjeldahl apparatus was used to digest $1.5 \mathrm{~g}$ of each sample in a diacid mixture $\left(\mathrm{HNO}_{3}: \mathrm{HClO}_{4}, 5: 1, \mathrm{v} / \mathrm{v}\right)$. The digested sample was used for the determination of sodium, potassium, calcium, iron, zinc, and magnesium using atomic absorption spectrophotometer (Jenway, Model 7315; Bibby Scientific Ltd, UK). Phosphorus concentration was determined by measuring the absorbance of the yellow colour formed by the reaction of the element with molybdate vanadate solution (AOAC, 2005). 


\section{Determination of amino acids}

The amino acid composition was determined using the modified method 982.30 of AOAC (2005). The sample was defatted, hydrolysed, and then derivatised. The derivatised sample solution that was free of derivatising reagents was made up to $1 \mathrm{ml}$ volume in a vial and then injected into Gas Chromatography (HP 6890 Powered with HP ChemStation Rev. A09.01 [1206] software) for amino acids analysis. Hydrogen was used as carrier gas with a flow rate of $1.0 \mathrm{ml} / \mathrm{minute}$, column dimension was $1.0 \mathrm{~m} \times 0.2 \mathrm{~mm} \times 0.25 \mu \mathrm{m}$, the initial oven temperature was $110^{\circ} \mathrm{C}$, ramped at $27^{\circ} \mathrm{C} /$ minutes to $320^{\circ} \mathrm{C}$ and maintained at $320^{\circ} \mathrm{C}$ for 5 minutes. The amount of each amino acid present in the sample was calculated from the net weight and approximate area of each peak (representing each amino acid) and expressed as $\mathrm{g} / 100 \mathrm{~g}$ protein.

\section{Estimation of predicted protein efficiency ratio (P-PER)}

The Predicted Protein Efficiency Ratio (P-PER) was calculated from the amino acid composition using the equation of Alsmeyer et al. (1974) as reported by Arinola et al. (2019) (equation 1).

$$
\text { P-PER }=-0.468+0.454(\text { Leu })-0.105(\text { Tyr })
$$

\section{Resistant starch}

Resistant starch was determined under controlled enzymatic hydrolysis by incubating the sample with amylase and amyloglucosidase at $37^{\circ} \mathrm{C}$. Resistant starch (RS) is the starch that is not hydrolyzed after 120 minutes of incubation (Englyst $e t$ al., 1992).

\section{In vitro starch digestibility}

In vitro starch digestibility was determined according to the method described by Ogunka-Nnoka et al. (2020) with modification. The sample was dispersed in phosphate buffer and incubated with pancreatic amylase for 2 hours. After the incubation period, dinitrosalicylic acid was added to the reaction mixture and the absorbance was measured at $450 \mathrm{~nm}$. Glucose was used as a standard and the amount of glucose released was converted to starch by multiplying the percentage glucose concentration by a factor of 0.9. In vitro starch digestibility was expressed in percentage.

\section{Statistical analysis}

The difference in the experimental data was tested for statistical significance $\mathrm{p} \leq 0.05$ by Statistical Analysis of Variance (ANOVA) using the SPSS 21.0 software package (Statistical Package for Social Scientist, Michigan, USA).

\section{Results and discussion}

\section{Proximate Composition and Energy Value}

The proximate composition and energy value of breadfruit-bambara groundnut composite flours are presented in Table 1. Variation was generally observed in the values of moisture, protein, ash, fat, fiber, carbohydrate, and energy of the 
composite samples. The moisture contents of all the samples were within the range of 7.32 to $8.39 \%$, bambara groundnut appeared to increase the moisture content of the composite flours. The moisture content of flours, which is dependent on the materials used to produce the flour and on the efficiency of the drying method used, is a major parameter that influences the storage stability of dry food materials. Breadfruit flour alone had a protein content of 5.06\%, this value was increased to $16.96 \%$ at $40 \%$ level of bambara groundnut inclusion in the composite flours. Bambara groundnut is a leguminous crop rich in protein. The bambara flour contained $21.22 \%$ protein, $3.41 \%$ ash, $4.04 \%$ fat, $4.86 \%$ fibre, and $56.85 \%$ carbohydrate.

Table 1. Proximate composition (\%) and energy value (kcal/100g) of breadfruit-bambara groundnut composite flours.

\begin{tabular}{lcclcc}
\hline & BBG1 & BBG2 & BBG3 & BBG4 & BBG5 \\
\hline Moisture & $7.32 \pm 0.24^{\mathrm{b}}$ & $7.26 \pm 0.19^{\mathrm{b}}$ & $8.03 \pm 0.11^{\mathrm{a}}$ & $8.22 \pm 0.21^{\mathrm{a}}$ & $8.39 \pm 0.27^{\mathrm{a}}$ \\
Protein & $5.06 \pm 0.20^{\mathrm{e}}$ & $7.77 \pm 0.15^{\mathrm{d}}$ & $9.23 \pm 0.09^{\mathrm{c}}$ & $13.11 \pm 0.13^{\mathrm{b}}$ & $16.96 \pm 0.24^{\mathrm{a}}$ \\
Ash & $1.54 \pm 0.03^{\mathrm{c}}$ & $1.78 \pm 0.01^{\mathrm{bc}}$ & $1.93 \pm 0.02^{\mathrm{bc}}$ & $2.23 \pm 0.4^{\mathrm{ab}}$ & $2.71 \pm 0.00^{\mathrm{a}}$ \\
Fat & $1.06 \pm 0.02^{\mathrm{c}}$ & $1.24 \pm 0.01^{\mathrm{c}}$ & $1.37 \pm 0.01^{\mathrm{bc}}$ & $1.74 \pm 0.03^{\mathrm{ab}}$ & $1.96 \pm 0.01^{\mathrm{a}}$ \\
Crude fibre & $5.33 \pm 0.11^{\mathrm{a}}$ & $5.39 \pm 0.08^{\mathrm{a}}$ & $5.01 \pm 0.12^{\mathrm{ab}}$ & $4.83 \pm 0.10^{\mathrm{b}}$ & $4.65 \pm 0.09^{\mathrm{b}}$ \\
Carbohydrate & $79.69 \pm 0.36^{\mathrm{a}}$ & $76.56 \pm 0.41^{\mathrm{b}}$ & $74.43 \pm 0.24^{\mathrm{c}}$ & $69.87 \pm 0.54^{\mathrm{d}}$ & $65.33 \pm 0.48^{\mathrm{e}}$ \\
Energy value & 348.54 & 348.48 & 346.97 & 347.58 & 346.80 \\
\hline
\end{tabular}

Values are means of three determinations. Values in the same row with different superscript are significantly different $(\mathrm{p} \leq 0.05)$. BBG1 $=$ Breadfruit flour 100: Bambara groundnut flour $0 ; \mathrm{BBG} 2=$ Breadfruit flour 90: Bambara groundnut flour 10; BBG3 = Breadfruit flour 80: Bambara groundnut flour 20; BBG4 = Breadfruit flour 70: Bambara groundnut flour 30; BBG5 = Breadfruit flour 60: Bambara groundnut flour 40

Protein is a major index of flour quality which influences the quality of end products (Raihan and Saini, 2017). The range of protein content in this study was higher than the range $4.68-13.03 \%$ reported for sweet potato-lima beans composite flours (Olaleye et al., 2020). The appreciable protein content of breadfruit-bambara groundnut composite flours suggests that it can be used in various forms either as weaning food, baked products, or dumpling dough to boost protein intake especially among poor people of rural areas.

The ash content increased marginally with an increase in the proportion of bambara groundnut in the composite fours. However, this increase was significant at a higher level of bambara groundnut inclusion. The same pattern of the result was observed for fat contents, fat content ranged from 1.06 to $1.96 \%$, this value was lower than $2.14-4.02 \%$ reported for maize-lima beans flour blends (Oluwafemi et al., 2018). This low-fat content of breadfruit-bambara groundnut composite flours may indicate low susceptibility to lipid peroxidation, a major deteriorative change 
in high fat containing food materials during storage. The low-fat content may also make the breadfruit-bambara groundnut composite flours a choice ingredient in aqueous food systems where high-fat content will interfere with the desirable quality of such products. However, the fat contents of the composite flours were lower than the value generally expected in complementary foods. The inclusion of bambara groundnut caused a marginal reduction in the fibre content of the composite flours from $5.33 \%$ at $0 \%$ level of bambara groundnut inclusion to $4.65 \%$ at $40 \%$ level of inclusion of the leguminous crop. The values of the fibre content were higher than $1.01-2.48 \%$ reported for composite flours produced from oats, sorghum, amaranth and wheat flour (Raihan and Saini, 2017). This relatively high fibre content is of advantage especially in food formulations meant for adolescents and adults because fibre has been noted to help control the absorption of blood sugar which is critical for diabetics. It also increases the movement of bile salts derivatives (potential carcinogens) in the intestines thereby reducing the occurrence of colon malignant tumors (Mongi et al., 2011). Breadfruit flour alone had the highest carbohydrate value. Breadfruit, unlike bambara groundnut, is rich in starch, which is a major carbohydrate component and a major energy source in the body. There was a reduction in the carbohydrate content of other samples as the level of bambara groundnut increased in the composite flours. The energy values ranged from 346.80 to $348.54 \mathrm{kcal} / 100 \mathrm{~g}$, this range was lower than the $345.85-372.75$ $\mathrm{kcal} / 100 \mathrm{~g}$ reported for composite flours produced from unripe banana, pigeon pea, and sweet potato flours (Ohizua et al., 2017).

\section{Mineral Composition}

There were significant differences in the values of mineral elements of the samples (Table 2); mineral elements are important nutrients that are needed for normal body metabolism, development and maintenance of bones, teeth, tissues, muscles, blood, nerve cells and to facilitate the normal function of some vital organs in the body. Sodium and potassium content ranged from $48.64-71.25 \mathrm{mg} / 100 \mathrm{~g}$ and 727.82 $797.73 \mathrm{mg} / 100 \mathrm{~g}$ respectively. Sodium content reduced with an increase in the level of bambara groundnut while the opposite trend was observed for potassium. However potassium contents are several folds $(10-16)$ higher than the sodium content, this is of important health implication in the body. High potassium to sodium ratio is usually recommended in the diet due to its positive effect in reducing high blood pressure, (Aremu et al., 2006; Arinola et al., 2019). The two mineral elements are involved in the regulation and maintenance of $\mathrm{pH}$ and the osmotic balance of body fluid. Sodium and potassium contents of the samples were higher than the range of $2.51-11.67 \mathrm{mg} / 100 \mathrm{~g}$ and $1.65-18.40 \mathrm{mg} / 100 \mathrm{~g}$ respectively reported for composite flours produced from unripe banana, pigeon pea, and sweet potato flours (Ohizua et al., 2017). There was a reduction in the calcium content of the composite flours as the level of bambara groundnut increased, the values ranged from $57.65-64.50 \mathrm{mg} / 100 \mathrm{~g}$, this range was higher than the range $(2.27-6.92 \mathrm{mg} / 100)$ reported for plantain-tiger nut composite flours (Adegunwa et al., 2017). 
Phosphorus content of $60 \%$ breadfruit and $40 \%$ bambara groundnut composite flour was the highest with a value of $177.32 \mathrm{mg} / 100 \mathrm{~g}$. The phosphorus contents reported in this study were higher than the values $32.65-120.65 \mathrm{mg} / 100$ reported for plantain-tiger nut composite flours (Adegunwa et al., 2017) but lower than $145.76-242.51 \mathrm{mg} / 100 \mathrm{~g}$ reported for breadfruit-soybean flour blends (Arinola $e t$ al., 2020). Calcium and phosphorus among other functions are essentials for the development and maintenance of healthy bone and teeth, the relatively high contents of these two mineral elements would therefore make the composite flours to be of immense nutritional benefit to children and aged people. Iron, zinc, and magnesium contents ranged from 4.08 to $4.51 \mathrm{mg} / 100 \mathrm{~g}, 3.19$ to $3.52 \mathrm{mg} / 100 \mathrm{~g}$, and 92.71 to $117.05 \mathrm{mg} / 100 \mathrm{~g}$ respectively. The difference in the values of iron and zinc was not significant, however for magnesium, there was a significant difference. Values of magnesium increased with increase in the level of bambara groundnut. The iron content of the composite flours was higher than 1.2 to $2.4 \mathrm{mg} / 100 \mathrm{~g}$ reported for wheat-soybean flour blends (Akubor and Fayashe, 2018); magnesium value was however lower than the range of $70.89-753.60 \mathrm{mg} / 100 \mathrm{~g}$ reported for composite flours produced from unripe banana, pigeon pea, and sweet potato flours (Ohizua et al., 2017). Iron and zinc are essentials for blood building and enhancement of the body's immune system respectively, while magnesium is vital for the activities of cellular enzymes that are involved in energy utilization.

Table 2. Mineral composition (mg/100g) of breadfruit-bambara groundnut composite flours.

\begin{tabular}{llclll}
\hline Samples & BBG1 & BBG2 & BBG3 & BBG4 & BBG5 \\
\hline Na & $71.25 \pm 1.06^{\mathrm{a}}$ & $68.73 \pm 0.91^{\mathrm{b}}$ & $62.96 \pm 1.00^{\mathrm{c}}$ & $56.03 \pm 2.01^{\mathrm{d}}$ & $48.64 \pm 0.86^{\mathrm{e}}$ \\
$\mathbf{K}$ & $727.82 \pm 2.21^{\mathrm{e}}$ & $739.09 \pm 1.16^{\mathrm{d}}$ & $756.54 \pm 0.97^{\mathrm{c}}$ & $781.39 \pm 1.90^{\mathrm{b}}$ & $797.73 \pm 2.26^{\mathrm{a}}$ \\
$\mathbf{C a}$ & $64.50 \pm 0.83^{\mathrm{a}}$ & $63.80 \pm 1.03^{\mathrm{a}}$ & $61.02 \pm 0.96^{\mathrm{b}}$ & $58.12 \pm 0.73^{\mathrm{c}}$ & $57.65 \pm 1.01^{\mathrm{c}}$ \\
$\mathbf{P}$ & $143.36 \pm 1.19^{\mathrm{e}}$ & $148.31 \pm 0.93^{\mathrm{d}}$ & $159.00 \pm 0.86^{\mathrm{c}}$ & $168.56 \pm 1.27^{\mathrm{b}}$ & $177.32 \pm 1.00^{\mathrm{a}}$ \\
$\mathbf{F e}$ & $4.15 \pm 0.16^{\mathrm{a}}$ & $4.08 \pm 0.10^{\mathrm{a}}$ & $4.46 \pm 0.09^{\mathrm{a}}$ & $4.39 \pm 0.12^{\mathrm{a}}$ & $4.51 \pm 0.15^{\mathrm{a}}$ \\
$\mathbf{Z n}$ & $3.34 \pm 0.07^{\mathrm{a}}$ & $3.19 \pm 0.11^{\mathrm{a}}$ & $3.38 \pm 0.09^{\mathrm{a}}$ & $3.52 \pm 0.00^{\mathrm{a}}$ & $3.50 \pm 0.11^{\mathrm{a}}$ \\
$\mathbf{M g}$ & $92.71 \pm 1.00^{\mathrm{d}}$ & $93.43 \pm 1.12^{\mathrm{d}}$ & $98.65 \pm 1.36^{\mathrm{c}}$ & $107.92 \pm 1.11^{\mathrm{b}}$ & $117.05 \pm 1.06^{\mathrm{a}}$ \\
\hline
\end{tabular}

Values are means of three determinations. Values in the same row with different superscript are significantly different $(\mathrm{p} \leq 0.05)$. BBG1 $=$ Breadfruit flour 100: Bambara groundnut flour $0 ; \mathrm{BBG} 2=$ Breadfruit flour 90: Bambara groundnut flour 10; BBG3 = Breadfruit flour 80: Bambara groundnut flour 20; BBG4 = Breadfruit flour 70: Bambara groundnut flour 30; BBG5 = Breadfruit flour 60: Bambara groundnut flour 40 .

\section{Amino Acid Composition}

Amino acids generally play important roles in various metabolic activities and processes in the body such as the building of proteins and synthesis of hormones; of particular interest are the essential ones that must necessarily be derived from food because the body cannot synthesize them. 
Table 3. Amino acid composition of breadfruit-bambara groundnut composite flours.

\begin{tabular}{|c|c|c|c|c|c|}
\hline $\begin{array}{l}\text { Amino acid, } g / 100 \mathrm{~g} \\
\text { protein }\end{array}$ & BBGl & BBG2 & BBG3 & BBG4 & BBG5 \\
\hline Glycine & $3.77 \pm 0.02^{\mathrm{bs}}$ & $3.93 \pm 0.02^{b}$ & $3.55 \pm 0.01^{=}$ & $4.62 \pm 0.02^{2}$ & $3.98 \pm 0.01^{b}$ \\
\hline Alanine & $3.43 \pm 0.01^{=}$ & $3.37 \pm 0.01=$ & $3.35 \pm 0.02^{=}$ & $3.39 \pm 0.02^{=}$ & $3.22 \pm 0.01=$ \\
\hline Serine & $4.54 \pm 0.02^{b}$ & $5.45 \pm 0.02^{=}$ & $4.16 \pm 0.01^{=}$ & $4.48 \pm 0.01^{b}$ & $4.64 \pm 0.02^{\mathrm{b}}$ \\
\hline Proline & $6.69 \pm 0.01^{=}$ & $7.73 \pm 0.01^{=}$ & $7.01 \pm 0.03^{b}$ & $6.63 \pm 0.02^{=}$ & $5.56 \pm 0.01^{\mathrm{d}}$ \\
\hline Valine* & $4.61 \pm 0.03^{b}$ & $4.38 \pm 0.02^{z}$ & $4.35 \pm 0.02^{\varepsilon}$ & $4.58 \pm 0.01^{\mathrm{bs}}$ & $4.86 \pm 0.01=$ \\
\hline Threonine* & $4.01 \pm 0.01^{b}$ & $4.34 \pm 0.01=$ & $3.74 \pm 0.03^{=}$ & $3.99 \pm 0.01^{\mathrm{b}}$ & $3.24 \pm 0.02^{\mathrm{d}}$ \\
\hline Isoleucine* & $3.32 \pm 0.02^{=}$ & $3.55 \pm 0.02^{\varepsilon}$ & $4.02 \pm 0.02^{2 b}$ & $3.85 \pm 0.02^{b}$ & $4.17 \pm 0.03^{2}$ \\
\hline Leucine $^{*}$ & $7.02 \pm 0.03^{b}$ & $6.92 \pm 0.03^{b}$ & $7.63 \pm 0.02=$ & $7.83 \pm 0.02=$ & $6.53 \pm 0.01^{=}$ \\
\hline Aspartic Acid & $7.33 \pm 0.04=$ & $6.48 \pm 0.01^{=}$ & $6.77 \pm 0.01^{b}$ & $6.88 \pm 0.03^{b}$ & $5.80 \pm 0.02^{\mathrm{d}}$ \\
\hline Lysine ${ }^{*}$ & $3.57 \pm 0.01^{=}$ & $2.96 \pm 0.01^{b}$ & $3.67 \pm 0.02^{z}$ & $3.72 \pm 0.01^{=}$ & $2.85 \pm 0.01^{b}$ \\
\hline Methionine* & $1.41 \pm 0.01^{\mathrm{b}}$ & $1.24 \pm 0.01^{=}$ & $1.40 \pm 0.01^{\mathrm{b}}$ & $1.67 \pm 0.01^{=}$ & $1.26 \pm 0.01^{=}$ \\
\hline Glutamic Acid & $24.82 \pm 0.05^{=}$ & $26.29 \pm 0.03^{2}$ & $25.42 \pm 0.03^{\mathrm{b}}$ & $22.90 \pm 0.02^{\mathrm{a}}$ & $18.73 \pm 0.04=$ \\
\hline Phenylalanine* & $5.24 \pm 0.02^{\mathrm{b}}$ & $5.61 \pm 0.02^{=}$ & $5.15 \pm 0.01^{\mathrm{b}}$ & $5.20 \pm 0.02^{\mathrm{b}}$ & $5.25 \pm 0.01^{\mathrm{b}}$ \\
\hline Histidine* & $2.58 \pm 0.01^{=}$ & $2.74 \pm 0.01=$ & $2.66 \pm 0.01^{=}$ & $1.94 \pm 0.02^{\mathrm{b}}$ & $2.13 \pm 0.01^{b}$ \\
\hline Arginine & $3.23 \pm 0.03^{b}$ & $3.29 \pm 0.02^{\mathrm{b}}$ & $3.19 \pm 0.02^{\mathrm{b}}$ & $3.22 \pm 0.01^{\mathrm{b}}$ & $4.97 \pm 0.01^{2}$ \\
\hline Tyrosine & $2.59 \pm 0.02^{=}$ & $3.60 \pm 0.02=$ & $2.55 \pm 0.01^{=}$ & $2.57 \pm 0.02^{\varepsilon}$ & $3.37 \pm 0.02^{b}$ \\
\hline Tryptophan ${ }^{*}$ & $1.47 \pm 0.01^{2}$ & $1.25 \pm 0.01^{\text {sac }}$ & $1.11 \pm 0.01^{=}$ & $1.20 \pm 0.01^{\mathrm{bs}}$ & $1.37 \pm 0.01^{2 b}$ \\
\hline Cystine & $1.90 \pm 0.02^{=}$ & $1.97 \pm 0.01^{\mathrm{bs}}$ & $2.23 \pm 0.02^{=}$ & $2.15 \pm 0.02^{2 b}$ & $1.52 \pm 0.01^{\mathrm{d}}$ \\
\hline Total Amino Acid & $91.53 \pm 0.03^{b}$ & $95.10 \pm 0.05^{2}$ & $91.96 \pm 0.02^{b}$ & $90.82 \pm 0.02=$ & $83.45 \pm 0.01^{\mathrm{d}}$ \\
\hline $\begin{array}{l}\text { Total Essential Amino } \\
\text { Acid }\end{array}$ & $33.23 \pm 0.02^{b}$ & $32.99 \pm 0.03^{b}$ & $33.73 \pm 0.02^{2}$ & $33.98 \pm 0.02^{2}$ & $31.66 \pm 0.03^{=}$ \\
\hline$\%$ TEAA & $36.31 \pm 0.02^{=}$ & $34.69 \pm 0.02^{\mathrm{a}}$ & $36.68 \pm 0.03=$ & $37.41 \pm 0.02^{\mathrm{b}}$ & $37.94 \pm 0.01^{=}$ \\
\hline $\begin{array}{l}\text { Total Non Essential } \\
\text { Amino Acid }\end{array}$ & $58.30 \pm 0.01^{\mathrm{b}}$ & $62.11 \pm 0.04^{2}$ & $58.23 \pm 0.02^{\mathrm{b}}$ & $56.84 \pm 0.03=$ & $51.79 \pm 0.02^{d}$ \\
\hline$\%$ TNEAA & $63.69 \pm 0.03^{b}$ & $65.31 \pm 0.03^{=}$ & $63.32 \pm 0.02^{\mathrm{b}}$ & $62.59 \pm 0.03=$ & $62.06 \pm 0.02^{\mathrm{a}}$ \\
\hline $\begin{array}{l}\text { Total Suphur Amino } \\
\text { Acid (Met + Cvs) }\end{array}$ & $3.31 \pm 0.01^{\mathrm{b}}$ & $3.21 \pm 0.02^{\mathrm{bs}}$ & $3.63 \pm 0.01^{2 b}$ & $3.82 \pm 0.02^{=}$ & $2.78 \pm 0.02^{=}$ \\
\hline$\%$ TSAA & $3.62 \pm 0.02^{\mathrm{bs}}$ & $3.38 \pm 0.01^{=}$ & $3.95 \pm 0.02^{2 b}$ & $4.21 \pm 0.01^{=}$ & $3.33 \pm 0.02^{=}$ \\
\hline $\begin{array}{l}\text { Total Acidic Amino } \\
\text { Acid (Asp+Glu) }\end{array}$ & $32.15 \pm 0.04^{\mathrm{b}}$ & $32.77 \pm 0.02^{2}$ & $32.19 \pm 0.02^{\mathrm{b}}$ & $29.78 \pm 0.01=$ & $24.53 \pm 0.02^{\mathrm{a}}$ \\
\hline$\%$ TAAA & $35.13 \pm 0.03^{2}$ & $34.46 \pm 0.02^{\mathrm{b}}$ & $35.00 \pm 0.03^{2}$ & $32.79 \pm 0.01^{=}$ & $29.39 \pm 0.01^{\mathrm{d}}$ \\
\hline $\begin{array}{l}\text { Total Basic Amino } \\
\text { Acid (Lys+His+Arg) }\end{array}$ & $9.38 \pm 0.01^{\mathrm{bs}}$ & $8.99 \pm 0.02^{\text {rd }}$ & $9.52 \pm 0.02^{z b}$ & $8.88 \pm 0.03^{\mathrm{d}}$ & $9.95 \pm 0.01^{=}$ \\
\hline$\%$ TBAA & $10.25 \pm 0.02^{\mathrm{b}}$ & $9.45 \pm 0.02^{=}$ & $10.35 \pm 0.02^{b}$ & $9.78 \pm 0.02^{=}$ & $11.92 \pm 0.02^{2}$ \\
\hline $\begin{array}{l}\text { Total Neutral Amino } \\
\text { Acid (TNAA) }\end{array}$ & $50.00 \pm 0.06^{=}$ & $53.34 \pm 0.03^{2}$ & $50.25 \pm 0.02=$ & $52.16 \pm 0.04^{b}$ & $48.97 \pm 0.03^{d}$ \\
\hline$\%$ TNAA & $54.63 \pm 0.03^{\mathrm{a}}$ & $56.09 \pm 0.02=$ & $54.64 \pm 0.02^{d}$ & $57.43 \pm 0.01^{\mathrm{b}}$ & $58.68 \pm 0.01^{=}$ \\
\hline $\begin{array}{l}\text { Predicted Protein } \\
\text { Efficiency Ratio }\end{array}$ & $2.45 \pm 0.02^{\text {sbe }}$ & $2.30 \pm 0.01^{\mathrm{bs}}$ & $2.73 \pm 0.02^{z b}$ & $2.82 \pm 0.01^{=}$ & $2.14 \pm 0.01^{=}$ \\
\hline
\end{tabular}

* Essential amino acids.

Values are means of three determinations. Values in the same row with different superscript are significantly different $(p \leq 0.05)$. BBG1 = Breadfruit flour 100: Bambara groundnut flour 0; BBG2 = Breadfruit flour 90: Bambara groundnut flour 10; BBG3 = Breadfruit flour 80: Bambara groundnut flour 20; BBG4 = Breadfruit flour 70: Bambara groundnut flour 30; BBG5 = Breadfruit flour 60: Bambara groundnut flour 40 
Amino acid composition of breadfruit-bambara groundnut composite flours (Table 3 ) revealed that all the essential amino acids were present in the composite flours; they constituted $34.69-37.94 \%$ of the total amino acid. These values were comparable to $36 \%$ considered for an ideal protein. A higher proportion of bambara groundnut in the composite flours caused a marginal increase in the percentage of essential amino acids. Leucine was the most abundant among the essential amino acid, followed by phenylalanine while methionine and tryptophan have the least values. Comparatively, breadfruit-bambara composite flours met the FAO/WHO (2007) requirement for adults and children (2-5 years) to a very large extent except for lysine, methionine, and phenylalanine for adults, and methionine for children. The ability of the samples to meet the FAO/WHO (2007) requirement for children coupled with the proportion of histidine, which is a major essential amino acid for children (for growth, creation of blood cells, and tissue repair) indicate that breadfruit-bamabara groundnut composite flours may be useful in formulating complementary foods.

The proportion of the two sulphur containing amino acids (methionine and cystine), which play important role in the health and flexibility of hair and skin, ranged from $3.33-4.21 \%$ of the total amino acid. The percentages of acidic, basic, and neutral amino acids in the samples were in the range $29.39-35.13 \%, 9.45$ $11.92 \%$, and $54.63-58.68 \%$ respectively of the total amino acid. The higher percentage of acidic amino acids over basic amino acids suggests that the protein component of the composite flour may be acidic; this may influence some functional properties such as foam formation which is dependent among other things on the $\mathrm{pH}$ of protein. Among all the amino acids glutamic acid was the most abundant with values ranging from $18.73 \mathrm{~g} / 100 \mathrm{~g}$ protein for the sample with the highest proportion of bambara groundnut to $26.29 \mathrm{~g} / 100 \mathrm{~g}$ protein for the sample with a $10 \%$ proportion of bambara groundnut. Similar highest level of glutamic acid was reported for potato, brown rice, soy, wheat, oat (Gorissen et al., 2018), and brown bambara groundnut (Oyeyinka 2017). It appears that glutamic acid is generally the most abundant amino acid in some food samples of plant origin. The predicted protein efficiency ratio, which was used as an index of protein quality in this study instead of an in-vivo experiment, ranged from 2.14 to 2.82. Sample with $30 \%$ proportion of bambara groundnut had the highest predicted protein efficiency ratio while sample with $40 \%$ proportion of bambara groundnut had the lowest. The predicted protein efficiency ratios of all the samples were however higher than 1.5, which is considered to be the minimum for a protein of good quality (Friedman, 1996).

\section{Resistant Starch and in vitro Starch Digestibility}

Resistant starch content and in vitro starch digestibility values are presented in Table 4. Resistant starch is the starch fraction that remains enzymatically undigested after the rapidly digestible and slowly digestible starch fractions have been digested in the small intestines. Resistant starch moves into the large intestine where it is fermented and exerts a physiological effect. The resistant starch content of breadfruit flour alone was $11.45 \%$. This value was lower than the average value 
of $46.03 \%$ reported for 21 Caribbean and Pacific breadfruit cultivars (Daley et al., 2019). This difference may be a result of cultivar differences. Some authors have reported differences in the quality attributes of breadfruit, these differences were as a result of variation in cultivar, production system, geographical location of cultivation, and environmental factors (Jones et al., 2011, Broomes et al., 2016). The resistant starch content of breadfruit flour was higher than the average value of $6.61 \%$ and $4.66 \%$ reported for some cultivars of cassava (Ogbon and Okafor, 2015) and sorghum (Souilah et al., 2014) respectively. The addition of bambara groundnut flour to breadfruit flour in the composite mixture increased the resistant starch content of the composite flours from 11.45 to $21.98 \%$. The trend of this result suggests that bambara groundnut had higher resistant starch content than breadfruit. Afolabi et al. (2018) reported 33\% resistant starch content for bambara groundnut flour. The difference in the resistant starch content of the two crops and their flour blends can be ascribed to differences in genetic composition, starch crystallinity, granular structure, amylose/amylopectin ratio, and interaction of starch with other macro and micro nutrients (Sajilata et al., 2006). The resistant starch contents of the samples were higher than the average of $8.78 \%$ reported for wheat-plantain-tigernut composite flours (Bamigbola et al., 2016). The relative high resistant starch content of breadfruit-bambara groundnut composite flours may suggest a reduced glycemic index.

In vitro starch digestibility is an index of nutritionally important starch fractions in a sample and may also give an indication of the capacity of the sample to contribute to postprandial hyperglycemia. The in vitro starch digestibility of the composite flours ranged from 40.41 to $58.75 \%$, increase in the level of bambara groundnut reduced the in vitro starch digestibility, this may be as a result of the fact that the carbohydrate of bambara groundnut, like other leguminous crops, comprise a considerable quantity of oligosaccharides (raffinose and stachyose) which have poor digestibility tendency. The starch digestibility of the samples is expected to increase when they are processed and used in food formulations. This is due to the fact that processing, especially thermal processing usually facilitates the rupture of starch granules and disintegration of macromolecules, thereby enhancing their susceptibility to digestive enzymes. However, the extent of increase in starch digestibility depends on the crop, the types, and the duration of processing methods employed. Cooked and autoclaved mung bean flours were reported to exhibit a significant increase in in vitro starch digestion (Kaur et al., 2015) whereas cooking only had little effect on the in vitro starch digestion of rice flours (Wang et al., 2017). The in vitro starch digestibility of the composite flours in this study was lower than the range (41.55 to 76.93\%) reported for flours of nine sorghum cultivars (Souilah et al., 2014). The moderate in vitro starch digestibility values of the composite flour suggests that when it is used in food formulations and consumed, it may exhibit slow/delayed digestion and reduced glucose absorption thus blunting postprandial hyperglycemia. In vitro starch digestibility of the composite flours had a negative correlation $(-0.99, \mathrm{p} \leq 0.05)$ with resistant starch content. 
Table 4. Resistant starch content and in vitro starch digestibility of breadfruit-bambara groundnut composite flours.

\begin{tabular}{lcc} 
Samples & Resistant starch $(\%)$ & In vitro starch digestibility (\%) \\
\hline BBG1 & $11.45 \pm 0.15^{\mathrm{e}}$ & $58.75 \pm 0.65^{\mathrm{a}}$ \\
BBG2 & $12.78 \pm 0.25^{\mathrm{d}}$ & $54.60 \pm 0.42^{\mathrm{b}}$ \\
BBG3 & $15.76 \pm 0.20^{\mathrm{c}}$ & $49.23 \pm 0.70^{\mathrm{c}}$ \\
BBG4 & $19.25 \pm 0.15^{\mathrm{b}}$ & $43.92 \pm 0.33^{\mathrm{d}}$ \\
BBG5 & $21.98 \pm 0.35^{\mathrm{a}}$ & $40.41 \pm 0.49^{\mathrm{d}}$ \\
\hline
\end{tabular}

Values are means of three determinations. Values in the same column with different superscript are significantly different $(\mathrm{p} \leq 0.05)$. BBG1 = Breadfruit flour 100: Bambara groundnut flour 0; BBG2 = Breadfruit flour 90: Bambara groundnut flour 10; BBG3 = Breadfruit flour 80: Bambara groundnut flour 20; BBG4 = Breadfruit flour 70: Bambara groundnut flour 30; BBG5 = Breadfruit flour 60: Bambara groundnut flour 40

\section{Conclusions}

This study has shown that increased substitution of breadfruit flour with bambara groundnut flour improved the nutritional quality especially protein, ash, fat, potassium, phosphorus, and magnesium contents of the composite flours. The amino acids composition and predicted protein efficiency ratio indicates composite flours with appreciable protein quality. The inclusion of bambara groundnut increased the resistant starch content while it reduced the in vitro starch digestibility, this suggests that the composite flours may not result in significant postprandial hyperglycemia. It may be concluded that the composite flours have good nutritional and functional potentials which may qualify them for use in food formulations.

\section{References}

Adegunwa, M.O., Adelekan, E.O., Adebowale, A.A., Bakare, H.A., Alamu, E.O. 2017. Evaluation of nutritional and functional properties of plantain (Musa paradisiaca L.) and tigernut (Cyperus esculentus L.) flour blends for food formulations. Cogent Chemistry, 3, 1383707.

Afolabi, T.A., Opara, A.O., Kareem, S.O., Oladoyinbo, F.O. 2018. In vitro digestibility of hydrothermally modified Bambara groundnut (Vigna subterranean L.) starch and flour. Food Science and Nutrition, 6, 36-46.

Akubor, P.I., Fayashe, T.O. 2018. Chemical composition, functional properties and performance of soybean and wheat flour blends in instant fried noodles. South Asian Journal of Food Technology and Environment, 4 (2), 690 - 699.

Alsmeyer, R.H., Cunningham, A.E., Happich, M.L. 1974. Equation to predict protein efficiency ratio (PER) from amino acid analysis. Food Technology, 28, 34-38.

AOAC. 2005. Official Method of Analysis. $18^{\text {th }}$ Edn. Association of Official Analytical Chemists. Washington D. C.

Aremu, M.O., Olaofe, O., Akintayo, E.T. 2006.Compositional evaluation of cowpea (Vigna unquiculata) and scarlet runner bean (Phaseolus coccineus) varieties grown in Nigeria. Journal of Food Agriculture and Environment, 4 (2), 39-43. 
Arinola, S.O., Ojo, T.P., Akinmolayan, J.O., Kehinde, A.O. 2020. Evaluation of Nutritional Composition and Sensory Attributes of Breadfruit-Soybean Flour Blends for Complementary Foods. Asian Food Science Journal, 16 (2), 13-21.

Arinola, S.O., Oje, O.J., Omowaye-Taiwo, O.A. 2019. Some nutritional properties and antioxidant activity of African locust bean (Parkia biglobosa) pulp. Annals. Food Science and Technology, 20 (2), 355 -361.

Bamigbola, Y.A., Awolu, O.O., Oluwalana, I.B. 2016. The effect of plantain and tigernut flours substitution on the antioxidant, physicochemical and pasting properties of wheat based composite flours. Cogent Food \& Agriculture, 2 (1), 1245060.

Bodinham, C.L., Smith, L., Thomas, E.L., Bell, J.D., Swann, J.R., Costabile, A., RussellJones, D., Umpleby, A.M., Robertson, M.D. 2014. Efficacy of increased resistant starch consumption in human type 2 diabetes. Endocrine Connections, 3, 75-84.

Broomes, J., Badrie, N., Roberts-Nkrumah, L.B. 2016. The characterization of starch from selected breadfruit (Artocarpus altilis) cultivars at two stages of maturity. Tropical Agriculture (Trin.), 93 (1), 154-171.

Bugusu, B.A., Campanella, O., Hamaker, B.R. 2001. Improvement of sorghum-wheat composite dough rheological properties and breadmaking quality through Zein addition. Cereal Chemistry, 78 (1), $31-35$.

Daley, O.O., Roberts-Nkrumah, L.B., Alleyne, A.T., Francis-Granderson, I., Broomes, J., Badrie, N. 2019. Assessment of breadfruit (Artocarpus altilis, (parkinson) fosberg) cultivars for resistant starch, dietary fibre and energy density. African Journal of Food, Agriculture, Nutrition and Development, 19 (4), 15060-15076.

Englyst, H.N., Kingman, M., Cummings, J.H. 1992. Classification and measurement of nutritionally important starch fractions. European Journal Clinical Nutrition, 46 (2), S33-S50.

FAO/WHO 2007. Protein and amino acid requirements in human nutrition. Report of a Joint WHO/FAO/UNU Expert Consultation, WHO technical report series no. 935. Geneva, Switzerland: World Health Organization.

Friedman, M.C. 1996. Nutritional value of protein from different food sources: A review. Journal of Agriculture and Food Chemistry, 44 (1), 6-29.

Gorissen, S.H.M., Crombag, J.J.R., Senden, J.M.G., Waterval, W.A.H, Bierau, J., Verdijk, L. B., van Loon, L.J.C. 2018. Protein content and amino acid composition of commercially available plant-based protein isolates. Amino Acids, 50, 1685-1695.

Jones, A.M.P, Ragone, D., Tavana, N.G., Bernotas, D.W., Murch, S.J. 2011. Beyond the bounty:Breadfruit (Artocarpus altilis) for food security and novel foods in the $21^{\text {st }}$ century. Ethnobotany Research \& Applications, 9, 129-149.

Kaur, M., Sandhu, K.S., Ahlawa, R., Sharma, S. 2015. In vitro starch digestibility, pasting and textural properties of mung bean: effect of different processing methods. Food Science and Technology, 52 (3), 1642-1648.

Mazahib, A.M., Nuha, M.O., Salawa I.S., Babiker, E.E. 2013. Some nutritional attributes of bambara groundnut as influenced by domestic processing. International Food Research Journal, 20 (3), 1165-1171.

Mongi, R.J., Ndabikunze, B.K., Chove, B.E., Mamiro, P., Ruhembe, C.C., Ntwenya, J.G. 2011. Proximate composition, bread characteristics and sensory evaluation of cocoyam-wheat composite breads. African Journal of Food, Agriculture, Nutrition and Development, 11 (7), 5586 - 5599.

Noorfarahzihah, M., Lee, J.S., Sharifudin, M.S., Mohd-Fadzelly, A.B., Hasmadi, M. 2014. Application of composite flour in development of food products. International Food Research Journal, 21, 2061-2074. 
Ogbon, F.C., Okafor, E.N. 2015. The resistant starch content of some cassava based Nigerian foods. Nigerian Food Journal, 33, 29-34.

Ogunka-Nnoka, C.U., Ben-piakor, T.E., Mepba, H.D. 2020. In vitro digestibilities, predicted glycemic index and sensory evaluation of biscuits produced from composite flours of wheat and processed tiger nut. GSC Biological and Pharmaceutical Sciences, 10 (3), 164-172.

Ohizua, E.R., Adeola, A.A., Micheal, A.I., Sobukola, O.P., Afolabi, T.A., Ishola, R.O., Ayansina, S.O., Oyekale, T.O., Falomo A. 2017. Nutrient composition, functional, and pasting properties of unripe cooking banana, pigeon pea, and sweet potato flour blends. Food Science and Nutrition, 5, 750-762.

Olaleye, H.T., Oresanya, T.O., Oladimeji, O.S., Okeke E.C. 2020. Quality Assessment of Cookies from Composite Flours of Sweet Potato (Ipomoea batatas L) And Lima Beans (Phaseolus lunatus). International Journal of Food Science and Nutrition Diet, 9 (3), 455-461.

Oluwafemi, G.I., Seidu, K.T., Akinruli, B.O. 2018. Production and Quality Evaluation of Maize Chips (Kokoro) Produced from Maize and Whole Lima bean Seed Flour Blends. Journal of Advancements in Food Technology, 1 (1), 1-7.

Oyeyinka, A.T. 2017. Nutritional, sensory and functional properties of a bambara groundnut complementary food. Ph.D. Thesis, Department of Dietetics and Human Nutrition, University of KwaZulu-Natal, Pietermaritzburg, South Africa.

Raihan, M., Saini, C. 2017. Evaluation of various properties of composite flour from oats, sorghum, amaranth and wheat flour and production of cookies thereof. International Food Research Journal, 24 (6), 2278-2284.

Sajilata, M.G., Singhal, S.R., Kulkarni P.R. 2006. Resistant Starch - A Review. Comprehensive Reviews in Food Science and Food Safety, 5, 1 - 17.

Souilah, R., Djabali, D., Belhadi, B., Mokrane, H., Boudries, N., Nadjemi, B. 2014. In vitro starch digestion in sorghum flour from Algerian Cultivars. Food Science \& Nutrition, 2 (3), 251-259.

Wang, S., Li, P., Zhang, T., Yu, J., Wang, S., Copeland, L. 2017. In vitro starch digestibility of rice flour is not affected by method of cooking. LWT Food science and Technology, 84, 536 - 543. 